\title{
Description and Histopathology Type of Pigmentosus Nevus in Dustira Hospital and Cibabat Hospital Cimahi
}

\author{
Aditya Yudha Pratama* \\ Medical Faculty \\ Universitas Jenderal Achmad Yani \\ Cimahi, Indonesia \\ *dr.pratamaaditya@gmail.com
}

\author{
Pisi Lukitto \\ Department of Surgery, Medical Faculty \\ Universitas Jenderal Achmad Yani \\ Cimahi, Indonesia
}

\author{
Lina Damayanti \\ Department of Dermatovenerology, Medical Faculty \\ Universitas Jenderal Achmad \\ Cimahi, Indonesia
}

\begin{abstract}
Pigmentosus Nevus is benign skin tumor which is the most common disease that has been found in many clinics. It comes from nevus cells that can produce melanin. Some types of nevus, such as junctional and compound nevus, can cause malignant melanoma which is a life-threatening skin cancer. Some risk factors that can cause pigmentosus nevus are age, genetic factors, and the exposure of UV light. The purpose of this research was to describe the patients of pigmentosus nevus based on some risk factors such as age, sex, the location of nevus, and histopathology type. Descriptive method was used and the objects of this research were medical records from pigmentosus nevus patients that has been treated by excisional surgery and has been examined by histopathology test from the 1st of January 2011 until the 31st of December 2015. The medical records were obtained from Dustira Hospital and Cibabat Hospital, Cimahi City. The results of this research showed that there were 55 cases of pigmentosus nevus found in 2011 - 2015 with 21 cases found in Dustira Hospital and 35 cases found in Cibabat Hospital, pigmentosus nevus mostly found in individuals aged 21-30 $(25,45 \%)$, mostly found in female patients $(65,45 \%)$, mostly located in the face and scalp $(90,90 \%)$, and the most common histopathological type was intradermal nevus $(94,55 \%)$.
\end{abstract}

Keywords—pigmentosus nevus, histopathological type

\section{INTRODUCTION}

Pigmentosus nevus or what is often referred to as melanocytic nevus or nevocellular nevus is a benign skin tumor with pigmentation that is most often found in clinics. Pigmentosus nevus originates from nevus cells and can produce melanin [1,2]. According to the histopathological features, pigmentosus can be divided into three types, there are the junctional type, the intradermal type, and the compound type [1].
Nevus can be found all over the body surface. The most common locations are the face and scalp, body, extremities, and some areas that are frequently exposed to sunlight [3]. There are several nevus locations that need to be suspected of being malignant, such as the nails and nail plates, the underarm fold area, the lower extremities (especially in women), the head and neck that need to be suspected as well [3-5].

Management of the pigmentosus nevus do if there are some problems such as aesthetical problem, irritation from clothing, and suspicion of malignancy (malignant melanoma), surgical excision can be carried out as its management. Pigmentosus nevus can be a sign, simultaneously, and a potential precursor to malignant melanoma [6]. The types of pigmentosus nevus that have a suspicion of malignancy are the junctional type and the compound type [1]. Clinically, two-thirds of existing nevuses can develop malignant melanoma, which is a malignant skin tumor [7]. A nevus that changes shape and color and it itches has a 400 times higher risk of becoming malignant [1,2]. These changes occur if there are risk factors in the form of trauma and chronic irritation. Signs and symptoms of these changes include increased nevus growth, pruritus, changes in pigmentation, ulceration, and spontaneous bleeding [7].

Nevus is owned by all humans of all age groups. It was found the same frequency in men and women [8]. In the adult with white skin, there are least 20 moles encountered, this number more than those with dark skin [1,9]. From the research of Arabia in 2005, the frequency of pigmentosus nevus in 2000-2003 at Hasan Sadikin Hospital Bandung was 60 people with the highest number of histopathological types being the intradermal type [10]. Besides that, the research conducted at the Skin and Genital Polyclinic of Prof. Dr. RD 
Kandou Manado in the period 2009-2011 found 26 cases of pigmentosus nevus [11].

There is still little public knowledge about pigmentosus nevus and there is still little existing data or previous research regarding the incidence of pigmentosus nevus. Therefore, it is necessary to conduct research to determine the amount of data. So, this research is a descriptive research which is limited to the description of pigmentosus nevus found in two hospitals in Cimahi City, which are Dustira Hospital and Cibabat Hospital.

From this background and research on pigmentosus nevus in the two hospitals, as well as several types of nevus that can turn malignant, researchers are interested in examining the histopathological features and types of pigmentosus nevus at Dustira Hospital and Cibabat Cimahi Hospital in the period $2011-2015$.

\section{METHODS}

This research was conducted in two hospital in Cimahi City, which are Dustira Hospital and Cibabat Hospital. Both hospital were Cimahi referral hospital, so it is expected that the number of cases found quite a lot. In addition, researchers hope that the data obtained can represent the population of Cimahi City. Method of this research used descriptive method with secondary data in the form of a medical record of patients diagnosed with pigmentosus nevus in the surgery department, dermatovenerology department, and pathology department of Dustira hospital and Cibabat Cimahi hospital period January $1^{\text {st }}, 2011$ until December 31 ${ }^{\text {st }}, 2015$, and have performed histopathological examination and have met the inclusion criteria in the form of a medical record that includes age, sex, location of the nevus, and type of histopathology and the exclusion criteria of this study are medical records that do not include histopathological type, unreadable doctor's writings, and pigmentosus nevus accompanied by other diseases. Data were collected using a total sampling method.

\section{RESULTS AND DISCUSSION}

Based on medical record data at Dustira Hospital and Cibabat Cimahi Hospital during the period January $1^{\text {st }}, 2011$ to December $31^{\text {st }}, 2015$, there were 154 cases of pigmentosus nevus. However, there were only 55 medical records that met the inclusion criteria, so the data collection method changed to total sampling because the minimum sample was not met. The exclusion of these medical records was because the data on the medical records were incomplete and the writings on the medical records were not readable.

\section{A. Distribution of Pigmentosus Nevus by Years}

In this study, the highest frequency of pigmentosus nevus was found in Dustira Hospital, namely in 2015 as many as 16 cases (76.20\%) and in Cibabat Hospital the most were found in 2014 with 10 cases (29.42\%). Pigmentosus nevus description based on the year of occurrence is described in table 1 .
Based on table 1, the number of cases of pigmentosus nevus in Cibabat Hospital was more than that of Dustira Hospital. The large number of cases is probably because Cibabat Hospital is a Cimahi City referral hospital so that there are referral patients from primary health services in the surrounding area. Increased patient in a given year in the hospital is likely because the patients who use the facilities BPJS Health, clinical concern would be the occurrence of malignancies, increasing diagnosis and cosmetic reasons.

TABLE I. Distribution of Pigmentosus NeVUS By YeARS

\begin{tabular}{|l|l|l|l|l|}
\hline \multirow{2}{*}{ Years } & \multicolumn{2}{|c|}{ Dustira Hospital } & \multicolumn{2}{c|}{ Cibabat Hospital } \\
\cline { 2 - 5 } & Amount & $\begin{array}{c}\text { Percentage } \\
(\%)\end{array}$ & \multicolumn{1}{c|}{ Amount } & $\begin{array}{c}\text { Percentage } \\
(\%)\end{array}$ \\
\hline 2011 & - & - & 5 & 14,70 \\
\hline 2012 & - & - & 5 & 14,70 \\
\hline 2013 & 1 & 4,76 & 6 & 17,65 \\
\hline 2014 & 4 & 19,04 & 10 & 29,42 \\
\hline 2015 & 16 & 76,20 & 8 & 23,53 \\
\hline Total & 21 & 100 & 34 & 100 \\
\hline
\end{tabular}

\section{B. Distribution of Pigmentosus Nevus by Group of Ages}

In this study, cases of pigmentosus nevus were mostly found in the age group of 21-30 years, with a total of 14 cases $(25.45 \%)$, while in the $0-10$ year age group and 71-80 years age group only found 1 case each $(1.82 \%)$. The number of cases in the 11 - 20 years age group and in the $31-40$ years age group were found 13 cases respectively $(23,64 \%)$. In the age group 41 - 50 years, the number of cases was 7 cases $(12,73 \%)$. The number of cases in the 51 - 60 years age group and in the $61-70$ years age group was found to be 3 cases each $(5.45 \%)$. These matters are described in table 2 .

TABLE II. Distribution of Pigmentosus NeVus by Group of Ages

\begin{tabular}{|l|l|l|}
\hline Group of Ages & Amount & Percentage (\%) \\
\hline $0-10$ & 1 & 1,82 \\
\hline $11-20$ & 13 & 23,64 \\
\hline $21-30$ & 14 & 25,45 \\
\hline $31-40$ & 13 & 23,64 \\
\hline $41-50$ & 7 & 12,73 \\
\hline $51-60$ & 3 & 5,45 \\
\hline $61-70$ & 3 & 5,45 \\
\hline $71-80$ & 1 & 1,82 \\
\hline Total & 55 & 100 \\
\hline
\end{tabular}

This study is in accordance with Shimizu's theory which states that pigmentosus nevus does not appear at birth but first occurs at the age of 3 and 4 years, and gradually increases in number and size [4]. Puberty is a period of active growth of nevus, then the density of nevus peaked in individual air- ages 20-29 years [12]. According to Schaffer and Bolognia in 2006 stated that the pigmentosus nevus peaked in the third decade and then regressed with age. It is also in line with the results of this study showing that the number of cases found pigmentosus nevus most in individuals aged 21-30 years (25.45\%) [13]. McCalmont stated that the incidence of pigmentosus nevus increases in the first three decades and the incidence of these 
cases will decrease in old age [14]. In addition, it is likely that the 21-30 year age group has the most cases because of the increased awareness of that age group to have their pigmentosus nevus checked.

\section{Distribution of Pigmentosus Nevus by Gender}

In this study, it was found that there were more pigmentosus nevus cases in female patients than male, with a total of 36 female patients $(65,45 \%)$ and 19 male patients $(34,55 \%)$ were described in the table 3 .

TABLE III. Distribution of Pigmentosus NevUs by Gender

\begin{tabular}{|l|l|l|}
\hline \multicolumn{1}{|c|}{ Gender } & Amount & Percentage (\%) \\
\hline Female & 36 & 64,45 \\
\hline Male & 19 & 34,55 \\
\hline Total & 55 & 100 \\
\hline
\end{tabular}

Based on the statement from Wolff that the pigmentosus nevus case between male and female is the same and the predilection of nevus is not influenced by gender [9]. However, in studies such as that conducted by Mackie, et al. conducted in 1985 on 432 Caucasians, nevus occurred higher in female patients with a mean total 33 nevuses than in male with a mean total of 22 nevuses [15]. In addition, based on research conducted by Tsaniyah, et al in 2015 regarding the histopathological picture of pigmentosus nevus at Dr. Mohammad Hoesin Palembang the period 2009-2013 indicates that pigmentosus nevus is more common in female $(67.1 \%)$ than male $(32.9 \%)$ with a ratio of female: male amounting to 2:1 [16]. Research conducted by Arabia in 2005 at Hasan Sadikin Hospital in Bandung found that the number of female patients is higher than male patients with a percentage of $65 \%$ : $35 \%$ [10]. This is consistent with this study which shows that pigmentosus nevus occurs more in female than male [10].

The large number of cases of pigmentosus nevus that occur in female is possibly based on cosmetic reasons, which can also interfere with appearance, so patients try to get rid of it. But additional data is needed such as the reason patients do nevus removal due to cosmetical factor or not.

\section{Distribution of Pigmentosus Nevus by Location of Nevus}

In this study, the location of the pigmentosus nevus was mostly on the face and scalp, with the number of cases of 50 cases $(90,90 \%)$. The number of patients with location of the nevus on the trunk and extremities was found in 2 cases $(3,64 \%)$. The number of patients with the location of the nevus on the neck was 1 case $(1,82 \%)$. There were no cases of pigmentosus nevus located at the back. These are described in table 4 below.
TABLE IV. Distribution of Pigmentosus Nevus By LoCATION OF NEVUS

\begin{tabular}{|l|l|l|}
\hline \multicolumn{1}{|c|}{ Location } & \multicolumn{1}{|c|}{ Amount } & Percentage (\%) \\
\hline Face and scalp & 50 & 90,90 \\
\hline Neck & 1 & 1,82 \\
\hline Body (chest and stomach) & 2 & 3,64 \\
\hline $\begin{array}{l}\text { Extremities (upper arms, } \\
\text { forearms, hand, thights, } \\
\text { calves, and feet) }\end{array}$ & 2 & 3,64 \\
\hline Total & 55 & 100 \\
\hline
\end{tabular}

Almost everyone has a pigmentosus nevus in varying amounts. Nevus can be found all over the body surface. The most common locations are the face and scalp, body, extremities, and some areas that are frequently exposed to sunlight [3].

Some data suggest that sunlight or ultraviolet rays can stimulate the development of pigmentosus nevus [14]. Countries with a population with white skin and high exposure to ultraviolet light have a higher prevalence of nevus, thus indicating that sunlight is nevogenic $[1,17]$. These things have a relationship with the results of this study. In this study, it was found that most of the nevus locations were the face and scalp area amounted 50 cases $(90,90 \%)$. This is because these areas are most often exposed to ultraviolet rays.

\section{E. Distribution of Pigmentosus Nevus by Histopatological Type}

Intradermal type pigmentosus nevus was the most common type in this study, with 52 cases $(94,55 \%)$. Another type that was found was the compound type, with the number of cases as much as 2 cases $(3,63 \%)$. In addition, a special variant of pigmentosus nevus, which is blue nevus, was found in 1 case $(1,82 \%)$. Other types were not found in this study. These are described in table 5 .

TABLE V. DistribUtion OF PIGMENTOSUS NEVUS BY HISTOPATOLOGICAL TYPE

\begin{tabular}{|l|l|l|}
\hline $\begin{array}{c}\text { Histopathological } \\
\text { Type }\end{array}$ & \multicolumn{1}{c|}{ Amount } & \multicolumn{1}{c|}{$\begin{array}{c}\text { Percentage } \\
(\%)\end{array}$} \\
\hline Intradermal & 52 & 94,55 \\
\hline Compound & 2 & 3,63 \\
\hline special variant: & & \\
\hline Blue nevus & 1 & 1,82 \\
\hline Total & 55 & 100 \\
\hline
\end{tabular}

The theory according to Unna which known as Abtropfung theory, the proliferation of melanocytes in the pigmentosus nevus develops from the epidermis and migrates to the dermis. This theory proves that the developmental stage in the natural history of pigmentosus nevus begins with junctional proliferation, then passes through the dermo-epidermal junction to become a compound nevus consisting of junctional and dermal components; then migrate completely into the dermis, losing the junctional component. In older individuals, an intradermal type of pigmentosus nevus is common, so this 
study is in accordance with the theory by Rosai and Burnett $[5,18]$. Research conducted by Arabia found that the most nevus type was intradermal type, with a percentage of $58.33 \%$ [10]. In this study also found the same type in the largest number, which is $94.55 \%$.

Other variants of pigmentosus nevus such as blue nevus was found in a small percentage, which is $1,82 \%$. Congenital giant pigmented nevus, spitz nevus, halo nevus, dysplastic nevus and so on were not found. This is consistent with the Robbin classification which classifies these nevuses into the less common / unusual mole [19].

\section{CONCLUSION}

The number of pigmentosus nevus cases in the period 2011 - 2015 at Dustira Hospital and Cibabat Hospital, Cimahi, found 55 cases of pigmentosus nevus. In Dustira Hospital, there were 21 cases and Cibabat Hospital as many as 34 cases of pigmentosus nevus. Pigmentosus nevus was found mostly in the age group of 21-30 years as many as 14 cases $(25,45 \%)$. Pigmentosus nevus was found mostly in female which is 36 cases $(64,45 \%)$. The location of the pigmentosus nevus that is most often found is on the face and scalp which is 50 cases $(90,90 \%)$. The most common histopathological type was the intradermal type in 52 cases $(94,55 \%)$.

\section{REFERENCES}

[1] S. Buditjahjono, Tumor-tumor kulit. In: Harahap M, editor. Ilmu penyakit kulit, 1st ed. Jakarta: Hipokrates Publisher, 2015, pp. 206-22.

[2] P. Casson and S. Colen, "Dysplastic and congenital nevi clinics in plastic surgery," Clinics in plastic surgery, vol. 20, no. (1), pp. 105-11, 1993.

[3] I. Pandhi, P. Shashi Bhushan, A.P. Sunil, and I.P. Sonam, "Melanocytic Tumors of The Skin: A Dermatopathological Review," Journal of Pigmentary Disorders, vol. 1, no. (3), pp. 2-10, 2014

[4] H. Shimizu, Shimizu's textbook of dermatology. Jepang: Hokkaido University Press, 2007, pp. 327-31.

[5] J. Rosai, Rosai and Ackerman's surgical pathology. 10th ed. Edinburgh London New York Oxford Philadelphia St Louis Sydney Toronto: Elsevier Mosby, 2011, pp. 151-73

[6] D.E. Elder, R. Elenitsas, G.F. Murphy, and X. Xu, "Benign pigmented lesions and malignant melanoma," In D.E. Elder, R. Elenitsas, G.F.
Murphy, and X. Xu, eds. Lever's histophatology of the skin. 10th ed. Philadelphia: Lippincott Williams \& Wilkins, 2009, pp. 669-711.

[7] J.A. Del Regato, H.J. Spjut, and J.D. Cox, Ackerman and del Regato's cancer diagnosis, treatment, and prognosis. St Louis Toronto Princeton: Mosby, 1985, pp. 207-25.

[8] R.S. Siregar, Atlas berwarna saripati penyakit kulit, 2nd ed. Jakarta: EGC Medical Book Publisher, 2002, pp. 275-6.

[9] J.M. Grichnik, A.R. Rhodes, and A.J. Sober, "Benign neoplasias and hyperplasias of melanocytes," In L.A. Gold Smith, S.I. Katz, B.A. Gilchrest, et al., editors. Fitzpatrick's dermatology in general medicine. 8th ed. New York Chicago San Francisco Lisbon London Madrid Mexico City Milan New Delhi San Juan Seoul Singapore Sydney Toronto: The McGraw-Hill Companies, 2012, pp. 1384-92.

[10] F. Arabia, Frekuensi nevus pigmentosus berdasarkan umur, jenis kelamin, lokasi, dan tipe histopatologi di Bagian/SMF Patologi Anatom FK UNPAD/RSHS Bandung Periode 2000-2003. Bandung: Faculty of Medicine Padjadjaran University, 2005.

[11] G.A. Gefilem, P.L. Suling, dan M.G. Kapantouw, Profil tumor jinak kulit di Poliklinik Kulit dan Kelamin RSUP Prof. Dr. R. D. Kandou Manado periode 2009-2011. Manado: Faculty of Medicine Sam Ratulangi University Manado, 2011

[12] M. Piepkorn and R.L. Barnhill, "Common acquired and atypical (dysplastic) melanocytic nevi," In R.L. Barnhill, M. Piepkorn, K.J. Busam, eds. Pathology of melanocytic nevi and malignant melanoma, 2nd ed. New York: Springer, 2004.

[13] J.V. Schaffer and J.L. Bolognia, "Melanocytic (nevocellular) nevi and their biology," In J.J. Nordlund et al., eds. The pigmentary system: physiology and pathophysiologety, 2nd ed. UK: Blackwell Publishing, 2006, p. 1120

[14] T. McCalmont, "Melanocytic nevi," 2015. [Online]. Retrieved from: http://emedicine.medscape.com/article/1058445-overview\#showall [Accessed on: March 19 $\left.9^{\text {th }}, 2021\right]$

[15] R.M. MacKie, J. English, T.C. Aitchison, C.P. Fitzsimons, and P. Wilson, "The number and distribution of benign pigmented moles (melanocytic naevi) in a healthy British population," British Journal of Dermatology, vol. 113, no. (2), pp. 167-174, 1985

[16] R.D. Tsaniyah, A. Aspitriani, and F. Fatmawati, "Prevalensi dan Gambaran Histopatologi Nevus Pigmentosus di Bagian Patologi Anatomi Rumah Sakit Dr. Mohammad Hoesin Palembang Periode 1 Januari 2009-31 Desember 2013," Majalah Kedokteran Sriwijaya, vol. 47, no. (2), pp. $110-114,2015$

[17] I.G.A.K. Rata, "Tumor Kulit," In A. Djuanda, M. Hamzah, S. Aisah, editor. Ilmu penyakit kulit dan kelamin, 5th ed. Jakarta: FKUI Publisher, 2008, pp. 229-41.

[18] M.E. Burnett, A.A. Marghoob, and A. Scope, "Nevogenesis: changing theories," In A.A. Marghoob, Eds. Nevogenesis: mechanisms and clinical implications of nevus development. New York: Springer, 2012 p. 2.

[19] V. Kumar, R.S. Cotran, dan S.L. Robbins, Buku ajar patologi, 7th ed Jakarta: ECG Medical Book Publisher, 2013, pp. 898-900. 